\title{
PENDIDIKAN AGAMA PADA ANAK BERKEBUTUHAN KHUSUS DI SMPLB SENTRA PENDIDIKAN KHUSUS DAN PENDIDIKAN LAYANAN KHUSUS
}

\section{Religious Education for Special Need Learners at SMPLB, the Center of Special Needs Education and Special Education Services}

\author{
Abdul Rahman Arsyad \\ Balai Penelitian dan Pengembangan Agama Makassar \\ Jl. A.P. Petta Rani No. 72 Makassar \\ Email: rahmanantang70@gmail.com
}

Naskah diterima tanggal 17 Februari 2014. Naskah direvisi tanggal 9 Maret 2014. Naskah disetujui tanggal 13 April 2014

\begin{abstract}
Abstrak
Penelitian ini menggunakan metode deskriptif kualitatif yang bertujuan untuk mengungkap bagaimana proses pelaksanaan pembelajaran pendidikan agama di Sekolah Luar Biasa (SLB) serta mengungkap faktor pendukung dan penghambat pelaksanaan pembelajaran pendidikan agama di Sentra Pendidikan Khusus dan Pendidikan Layanan Khusus (PK/PLK) Kab. Gorontalo. Hasil penelitian menunjukkan bahwa meskipun dengan fasilitas pembelajaran yang sangat terbatas, proses pelaksanaan pembelajaran pendidikan agama tetap berpedoman pada kurikulum Diknas, dengan menggunakan metode ceramah, demonstrasi, dan tanya jawab berdasarkan silabus yang diaplikasikan melalui RPP. Tenaga pendidik (guru agama) menggunakan metode pembelajaran pendidikan agama berdasarkan disabilitas dengan mengintegrasikan proses pembiasaan dan kreatifitas guru sebagai pelaksanaan pola pendidikan yang sesuai dengan karakter anak berkebutuhan khusus. Pola ini melahirkan output yang mengantarkan anak berkebutuhan khusus dalam memahami dan meyakini adanya Tuhan, mengenal kitab-kitab Allah, melaksanakan ibadah (shalat dan puasa), serta berperilaku yang terpuji. Pemahaman pendidikan agama diperkuat lewat bimbingan rohani, sedangkan proses pembentukan perubahan perilaku peserta didik dominan tercipta lewat pembelajaran/pembinaan yang dilaksanakan di luar kelas.
\end{abstract}

Kata kunci: difabel, SMPLB, pendidikan khusus, pendidikan agama

\begin{abstract}
This descriptive qualitative research aimed at revealing the implementation process of learning religious education in special schools and uncovering the supporting and inhibiting factors in implementing religious education learning in Special Needs Education and Special Education Services in Gorontalo regency. The results show that although learning facilities are not well adequate, the process of implementation of religious education learning keeps being guided by the Ministry of Education curriculum, by using the lecturing method, demonstration, as well as question and answer based on the syllabus applied through the lesson plans. The educators (teachers of religion) used religious education teaching methods based on disability by integrating the process of habituation and creativity of teachers as educational pattern implementation in accordance with the character of children with special needs. This pattern resulted outpot which bring special needs learners to understand and to believe the existence of God, to know the holy Books from God, to perform worship (praying and fasting), as well as to behave laudably. The understanding of religious education was strengthened through spiritual guidance, while the process of the building the learners' behavior change was dominantly created through learning conducted outside the classroom.
\end{abstract}

Keywords: disability, special education, religious education 


\section{PENDAHULUAN}

$\mathrm{P}$ endidikan adalah aspek yang sangat urgen dalam pembangunan bangsa, diarahkan untuk peningkatan ilmu, pengetahuan, keterampilan, sikap, kepribadian, dan akhlak mulia, tanpa terkecuali termasuk untuk Anak Kebutuhan Khusus (ABK).

Hak untuk memperoleh pendidikan merupakan hak semua warga negara, tidak terkecuali anak berkebutuhan khusus. Hal ini telah ditegaskan dalam UUD 1945 pasal 31 maupun pada UU No. 20 tahun 2003 tentang Sistem Pendidikan Nasioanl pasal 5 ayat 2 yang dengan tegas menyatakan bahwa "Warga negara yang memiliki kelainan fisik, emosional, mental, intelektual, dan/ atau sosial berhak memperoleh pendidikan khusus". Oleh karena itulah, sudah sewajarnya pemerintah dan kita semua memberikan perhatian yang baik terhadap penyelenggaraan pendidikan bagi anak berkebutuhan khusus.

Terjadi perkembangan pemikiran tentang pendidikan untuk anak yang berkebutuhan khusus. Pertama pemikiran segregasi, pemikiran bahwa anak yang berkebutuhan khusus dipisahkan dengan anak pada umumnya. Kedua pemikiran integrasi artinya anak yang berkebutuhan khusus dapat belajar dengan anak pada umumnya dengan suatu penekanan bahwa anak berkebutuhan khusus tersebut telah dipersiapkan dahulu dalam sekolah khusus dan ditempatkan sesuai dengan pengetahuannya bukan pada usianya. Ketiga pemikiran inklusi adalah anak yang berkebutuhan khusus dapat langsung bergabung dengan anak pada umumnya dalam menerima pendidikan.

ABK merupakan terjemahan dari istilah special needs children, dalam konteks Indonesia ABK mencakup beberapa kondisi, yaitu: gangguan penglihatan, wicara atau bahasa, komunikasi, pendengaran, perkembangan mental, motorik, emosi, dan gangguan tingkah laku.

Memperhatikan keterbatasan siswa dalam menerima pendidikan, maka guru sebagai ujung tombak dalam memberikan pelajaran tentu bekerja keras dan harus menemukan inovasi dalam memberikan ilmu pada anak yang berkebutuhan khusus.

Menurut data dari direktorat Pendidikan Khusus dan Layanan Khusus Kementerian Pendidikan dan Kebudayaan pada Rapat Koordinasi di Jakarta 2012, Sekolah Luar Biasa di Indonesia
(SDLB dan SMPLB) sebesar 1585 sekolah yang ratarata masih tersebar di ibukota provinsi di seluruh Indonesia.

Khusus untuk Provinsi Gorontalo sekolah yang menyelenggarakan pendidikan untuk anak berkebutuhan khusus sebanyak delapan SLB dengan jenjang SDLB, SMPLB, dan SMALB, yaitu: SLB Kota Gorontalo 1, SLB Gorontalo Utara 1, SLB Kab. Pohu Watu 1, Sentra PK/PLK SLB Kab. Gorontalo 1, SLB Kab. Bualemo 2, dan SLB Kab. Bone Bolango 2 sekolah.

Selama ini, sebagian orang membuat dikotomi antara normal dan cacat atau berkebutuhan khusus. Padahal, anak berkebutuhan khusus adalah bagian dari masyarakat juga, yang membutuhkan pendidikansamadenganorangyang tidakmengalami kekurangan (fisik atau psikis). Pendidikan bagi anak berkebutuhan khusus bertujuan untuk membentuk siswa yang mampu berprestasi dalam kelompoknya, baik secara sosial maupun emosional sebatas kemampuannya (Nuraeni, 1997:104-105)

Pendidikan Agama dimaksudkan untuk membentuk peserta didik menjadi manusia yang beriman dan bertakwa kepada Tuhan Yang Maha Esa dan berakhlak mulia serta peningkatan potensi spiritual sebagaimana juga telah diteskan dalam Keputusan Bersama Menteri Pendidikan dan Kebudayaan Dan Menteri Agama No.4/U/SKB/1999, dan Nomor: 570 tahun 1999, tentang Pelaksanaan Pendidikan Agama pada satuan pendidikan dasar dan menengah di lingkungan pembinaan Dirjen Dikdasmen.

Pendidikan agama dalam sistem pendidikan nasional merupakan salah satu jenis pendidikan yang didesain dan diberikan kepada peserta didik untuk mengembangkan keberagamaan mereka (Thoha, 1999:4). Hal ini mengisyaratkan bahwa dalam sistem pendidikan ada keseimbangan antara pengembangan potensi fisik dan mental, potensi intelektual dan spiritual, sebagai esensial dalam pembangunan manusia Indonesia seutuhnya.

Penelitian memfokuskan pada keterlaksanaan pembelajaran pendidikan agama yang dilakukan di Sekolah Luar Biasa di Propinsi Gorontalo. Adapun pertanyaan penelitian adalah: bagaimana pelaksanaan pembelajaran pendidikan agama pada Sekolah Luar Biasa (SLB), dan apa faktor pendukung dan penghambat dalam pelaksanaan pembelajaran pendidikan agama di SLB.

Sejalan dengan rumusan masalah maka tujuan penelitian ini adalah adanya gambaran deskriptif mengenai pendidikan agama, pada SLB 
Kab. Gorontalo; untuk mengetahui proses dan menemukan model pembelajaran pada SLB Kab. Gorontalo; untuk mengetahui kompetensi guru agama dalam melakukan pembelajaran pada SLB Kab. Gorontalo; untuk mengetahui pengembangan model pembelajaran pendidikan Agama di SLB yang selanjutnya dapat direkomendasikan sebagai masukan kebijakan dalam peningkatan kualitas pendidikan agama di SLB; untuk mengetahui faktor pendukung dan penghambat pelaksanaan pendidikan agama di SLB Kab. Gorontalo.

\section{METODE PENELITIAN}

Penelitian menggunakan metode kualitatif yang dilaksanakan di Sentra PK/PLK SLB Kab. Gorontalo dikonsentrasikan pada tuna netra, tuna tungu, dan tuna grahita. Adapun sumber data penelitian yaitu sumber primer disini adalah yang berhubungan langsung dengan obyek penelitian yaitu pendidik mata pelajaran Pendidikan Agama yang mengajar di SLB itu sendiri, karena penelitian ini tentang Pendidikan Agama maka secara tidak langsung guru-guru lainnya (di luar Guru Agama) yang memasukkan niali-nilai keagamaan juga menjadi masukan serta memberikan pengayaan pada penelitian ini. Sedangkan sumber sekunder dari penelitian ini adalah warga sekolah terkait yakni kepala SLB, orang tua siswa, serta dokumendokumen yang sifatnya sebagai pendukung.

Instrumen-instrumen yang digunakan untuk menggali data dalam penelitian ini didapat dengan menggunakan beberapa teknik yaitu: teknik observasi (pengamatan), teknik ini digunakan untuk mengetahui bagaimana pembelajaran agama yang dilaksanakan oleh guru di kelas dan diamati mulai dari materi pembuka, pembelajaran inti hingga penutup. Selain itu mengumpulkan data dan gambaran umum yang meliputi letak geografis, sarana dan prasarana, keadaan guru dan siswa; teknik interview atau wawancara, digunakan untuk memperoleh data mendalam mengenai metode atau model pembelajaran pendidikan agama yang dilakukan oleh guru agama di SLB. Teknik ini digunakan mulai dari interview partisipasi, identifikasi serta persuasi dengan informan untuk menggali faktor pendukung serta faktor penghambat selama proses belajar mengajar pendidikan agama di SLB. Teknik dokumentasi; digunakan untuk memperoleh dokumen-dokumen penting yang terkait dengan pelaksanaan pendidikan agama di SLB. Dokumen-dokumen tersebut meliputi sejarah SLB, tujuan pendirian sekolah, visi sekolah, kurikulum serta muatan kurikulum pendidikan agama.

Analisa data selama menggunakan model Spadley (Sugiono, 2005:346) dalam penelitian kualitatif maka proses penelitian berangkat dari yang luas, kemudian memfokus dan meluas lagi. Terdapat tahapan analisa data yang dilakukan dalam penelitian kualitatif, yaitu analisa domain, taksonomi dan komponensial, analisa tema kultural.

\section{PEMBAHASAN}

\section{Profil Sentra Pendidikan Khusus dan Pendidikan Layanan Khusus SLB Kabupaten Gorontalo}

Keberadaan gedung Sekolah Luar Biasa (SLB) yakni pada tahun 1984-1985, operasional pembelajaran saat itu masih pada tingkat SDLB di mulai pada tahun 1985-sekarang. Menurut Sahrin H. Inuka (Wakasek Bidang Sarana dan Prasarana), kondisi komponen pendidikan saat itu masih sangat terbatas, baik tenaga pendidik dan kependidikan, siswa, maupun sarana dan prasarana, sehingga proses pembelajaran pendidikan agama berlangsung secara sederhana, dalam arti guru hanya mengkondisikan. Untuk tingkat SMPLB operasional pembelajaran berlangsung sejak tahun 2001-sekarang, dan tingkat SMALB tahun 2007 sampai sekarang (wawancara, 12/3/2013).

Implementasi pendidikan agama yang berlangsung sejak tahun 1985 sampai sekarang belum memiliki tenaga pendidik (guru) agama dari Kementerian Agama, baik pada tingkat SD, SMP, maupun SMA. Sehingga Guru Agama yang ada di Sentra PK/PLK SLB Kabupaten Gorontalo saat ini berasal dari guru umum (regular) pengangkatan Kemendiknas. Dimana ketiga tingkatan memiliki masing-masing satu orang guru agama yang memiliki status yang berbeda, yakni : 1) guru agama SD (honorer) sebelumnya bertugas sebagai tenaga administrasi (computer); 2) guru agama SMP (PNS) sebelumnya bertugas pada sekolah umum; dan 3) guru agama SMA (honorer) sebelumnya adalah seorang muballiq di wilayah Kabupaten Gorontalo.

Keberadaan sekolah luar biasa (SLB) di Kabupaten Gorontalo, sudah dipimpin lima orang Kepala Sekolah, yaitu: Drs. Mus Lukum 1985-1991, Abraham Abdul Rahman Rivai 1991-1996, Maria Daulima 1996-2005, Yamin Umar, M.Pd 20052012, dan Salim Umar, S.Pd 2012-Sekarang. 
Menurut Yamin Umar (Mantan Kepsek SLB). Perubahan nomenklatur SDLB menjadi SENTRA PK/PLK sejak tahun 2001, atas kerja keras/usaha Bapak Yamin Umar dan kawan-kawan, dimana pihak sekolah menjual program ke Direktorat, guna mewujudkan perubahan tersebut. Adapun kreterianya, SLB harus memiliki 9 fasilitas keterampilan yang lengkap dan bisa dikembangkan. Sedangkan yang menada tangani Surat Keputusan adalah Bupati Kabupaten Gorontalo (wawancara, 17/3/2013).

Untuk profil tahun 2012 sampai sekarang adalah Sentra PK/PLK SLB Kabupaten Gorontalo beralamat di Jl. Muchtar Pulukadang No.152D, Desa Yosongeoro Kecamatan Limboto Barat Kabupaten Gorontalo, Tlp. (0435-882216) dengan Nomor Surat Sertifikat: 101290202041, sedangkan tahun didirikan 1984 dan operasional 1985. Status tanah dan bangunan milik pemerintah dengan ukuran $370 \mathrm{M}^{2}$.

Tabel 1 Jumlah Siswa dan Guru Agama

\begin{tabular}{llccccl}
\hline NO & JENJANG & \multicolumn{3}{c}{ SISWA } & GURU & KET \\
& & A & B & C & AGAMA & \\
\hline 1. & SD & 21 & 11 & 76 & 1 & Secara \\
2. & SMP & 3 & 1 & 12 & 1 & keseluruhan \\
3. & SMA & 2 & 3 & 4 & 1 & $\begin{array}{l}\text { jumlah guru 33 } \\
\text { dan siswa 148 }\end{array}$ \\
\hline Sumber: Profi SLB
\end{tabular}

Berdasarkan tabel di atas, menunjukkan bahwa data siswa difabel (tunanetra, tunarungu, dan tunagrahita) tahun 2012/2013 berdasarkan tingkat pendidikan SD, SMP, dan SMA secara keseluruhan berjumlah 33 guru dan 148 siswa.

\section{Proses Pembelajaran Pendidikan Agama}

Pelaksanaan pembelajaran pendidikan agama Islam diperlukan suatu proses serta unsur-unsur yang saling berkaitan antara satu dengan yang lainnya, sehingga proses pembelajaran pendidikan agama dapat menghasilkan suatu perubahan yang signifikan terhadap peserta didik. Kondisi proses pembelajaran pendidikan agama di Sentra PK/ PLK SLB Kabupaten Gorontalo. Peneliti melihat dari berbagai aspek, diantaranya: perencanaan, pelaksanaan, dan penilaian pembelajaran.

Proses pembelajaran pendidikan agama yang diterapkan sesuai dengan teori yang dikemukakan oleh Harun bahwa: Islam menggunakan gerak hati yang hidup dan intuitif, yang secara tiba-tiba membawa perasaan dari suatu situasi yang lain dan dari suatu perasaan ke perasaan yang lain. Lalu Islam tidak membiarkannya menjadi dingin, tetapi langsung mengubahnya menjadi kebiasaankebiasaan yang berkait dengan waktu, tempat, dan orang lain (Harun,1984:367).

\section{Rencana Pembelajaran}

Proses penyusunan rencana pembelajaran terdapat beberapa kendala yang dihadapi. Inilah yang menjadi permasalahan pokok yang harus diperhatikan dan memerlukan solusi pemecahan seperti: arah atau tujuan, evaluasi, isi dan urutan materi pelajaran, metode, dan hambatan-hambatan. (Sagala, 2005:48).

Menurut Ibu Nangsi Pakaya (Guru Agama SMPLB). Kurikulum yang digunakan dalam proses pelaksanaan pembelajaran pendidikan agama di Sentra PK/PLK SLB Kabupaten Gorontalo adalah kurikulum khusus Sekolah Luar Biasa (SLB) diterbitkan oleh Dirjen Manajemen Pendidikan Dasar Menengah dan Direktorat Pembinaan SLB tahun 2006. Sebahagian besar guru (agama dan umum) melakukan modifikasi kurikulum untuk menyesuaikan kemampuan dan kebutuhan siswa (wawancara, 19/3/2013).

Langkah-langkah kegiatan pembelajaran yang digunakan berdasarkan RPP yang disusun oleh guru agama melalui komponen silabus dan dikondisikan pada semester I dan II, dengan alokasi waktu $2 \times 35$ menit setiap pertemuan yang mengacu pada Standar Kompetensi (SK) dan Kompetensi Dasar (KD), materi pembelajaran; metode pembelajaran; dan kegiatan pembelajaran yang meliputi tahap pendahuluan, kegiatan inti, dan kegiatan penutup; sumber dan media; serta penilaian dan evaluasi.

Adapun materi pembelajaran pendidikan agama pada ABK yaitu: Alquran, Aqidah, Akhlak, Fiqih, dan Tarikh serta Hadlarah sedangkan proses pembelajaran dilaksanakan pada dua tempat, yaitu: ruang kelas dan mushallah. Untuk penilaian dari hasil pembelajaran pendidikan agama, dilakukan secara keseluruhan baik teori maupun praktik yang dinilai melalui guru agama.

\section{Pelaksanaan Pembelajaran}

Anak berkesulitan belajar yang memerlukan program pelayanan remedial, hendaknya 
dilaksanakan oleh guru khusus yang memiliki keahlian dalam bidang pendidikan yang diperuntukkan bagi anak berkesulitan belajar. Sebelum memberikan pengajaran remedial, terlebih dahulu guru perlu menegakkan diagnosis, yaitu menentukan jenis dan penyebab kesulitan serta alternatif strategi pengajaran remedial yang efektif dan efisien (Abdurrahman, 2003:63).

Dalam menyusun program, guru telah berusaha meracang program sesuai dengan kemampuan dan kriteria masing-masing anak didiknya. Persiapan guru sebelum memulai pelajaran sangat penting. Adanya persiapan yang matang akan menghasilkan pembelajaran yang efektif dan efesien. Kesiapan siswa sangat penting diperhatikan sebelum menerima materi yang akan diberikan oleh guru biasanya yang dipersiapkan siswa berhubungan dengan alat-alat tulis yang dipergunakan selama proses pembelajaran.

Penyajian materi banyak hal yang harus diperhatikan oleh guru, agar materi dapat tersampaikan dengan baik dan bisa diterima oleh siswa. Sehingga penyampaian materi tidak mengambang dan tidak membosankan siswa. Media yang digunakan oleh guru yaitu buku cerita merupakan media yang tersedia. Penggunaan metode disesuaikan dengan materi ajar yang akan disampaikan kepada siswa.

Menjadi seorangguru harus mampu mengelola kelas dengan baik, agar menciptakan suasana belajar yang nyaman dan tenang. Sehingga siswa dapat menyerap materi yang disampaikan oleh guru dengan baik. Tujuan pembelajaran dapat tercapai sesuai yang telah ditetapkan. Guru memberikan kesempatan pada siswa untuk berpartisipasi aktif dalam mengikuti proses pembelajaran. Pemberian penguatan merupakan cara guru agar siswa merasa lebih bersemangat dalam belajar dan membuat anak merasa tidak bosan di dalam kelas.

Pelaksanaan pembelajaran pendidikan agama secara integrasi, berdasarkan jenjang dan tingkat disabilitas, guna memudahkan dalam melangsungkan proses belajar mengajar serta mengevaluasi kemampuan siswa (wawancara dengan Salim Umar-Kepsek, 17/3/2013).

Adapun pengamatan sederhana yang dijadikan sebagai alat untuk mengukur tingkat perubahan siswa dalam memahami materi fiqih (mengenal tata cara shalat sunnat), dengan menggunakan metode pembelajaran ceramah serta media atau alat elektronik dan huruf braile pada tunanetra. Pengukuran target perilaku penguasaan materi dapat dilihat pada langkah-langkah pembelajaran, sebagai berikut:

\section{Kegiatan Pendahuluan}

Kebiasaan sebelum melangsungkan pembelajaran terlebih dahulu guru melakukan doa bersama, dengan meminta salah satu siswa untuk membaca surah al-Fatihah yang dipandu oleh guru. Kegiatan ini merupakan langkah awal untuk mengetahui kemampuan siswa tentang cara melafalkan al-Fatihah yang benar dalam shalat. Pembelajaran dilaksanakan secara pengabungan, guna memudahkan bagi guru dalam mentransformasikan materi pembelajaran serta menggunakan alokasi waktu sekitar 10 menit.

Pengamatan berlangsung secara bersamaan dalam satu kali pertemuan dan dilakukan berulangulang dengan waktu pengamatan \pm 40 menit (baseline dan intervensi). Proses ini merupakan cara untuk mengukur perilaku siswa tunanetra dalam penguasaan materi pelajaran.

Kemampuan siswa tunanetra dalam berdoa dan membaca al-Fatihah, sudah bisa melafalkan dan menghafal dengan benar. Penguasaan masih dalam sebatas lisan belum pada tahap penulisan. Siswa tunanetra melakukan pembiasaan menghafal dengan menggunakan hand phone sebagai alat bantu yang sering dilakukan saat istirahat, baik di asrama maupun di mushallah.

\section{Kegiatan Inti}

Proses pelaksanaan pembelajaran pada kegiatan inti memerlukan alokasi waktu 50 menit. Tenaga pendidik memberikan materi secara sistematis dengan menggunakan metode dan media berdasarkan bahan ajar tata cara shalat sunat. Adapun urutan kegiatan dalam mengajar yaitu: guru menjelaskan cara berwudhu, guru menjelaskan bacaan dan niat shalat sunnat, guru menjelaskan ketentuan dan tata cara shalat sunnat, dan guru memperaktekkan shalat sunnat.

Pengamatan sederhana terhadap penguasaan materi pelajaran shalat sunat pada anak tunanetra yang bernama Ibrahim Yusuf, dapat dijelaskan lewat tabel 2 sebagai berikut: 
Tabel 2. Target Behavior

\begin{tabular}{|c|c|c|c|c|}
\hline \multirow[t]{2}{*}{ NO } & \multirow[t]{2}{*}{ PENGUASAAN } & \multicolumn{2}{|c|}{$\begin{array}{l}\text { PENGA- } \\
\text { MATAN }\end{array}$} & \multirow[t]{2}{*}{ BAHAN AJAR } \\
\hline & & $\mathrm{A}$ & $\mathrm{B}$ & \\
\hline 1 & $\begin{array}{l}\text { Memahami materi } \\
\text { pelajaran }\end{array}$ & $70 \%$ & $68 \%$ & \multirow{6}{*}{$\begin{array}{l}\text { Doa al-Fatihah } \\
\text { Cara Berwudhu } \\
\text { Ketentuan Shalat } \\
\text { Bacaan dan Niat } \\
\text { Tata cara Shalat } \\
\text { Praktik Shalat }\end{array}$} \\
\hline 2 & $\begin{array}{l}\text { Memahami urutan } \\
\text { materi pelajaran }\end{array}$ & & $68 \%$ & \\
\hline 3 & Melaksanakan tugas & $68 \%$ & $70 \%$ & \\
\hline 4 & $\begin{array}{l}\text { Menyelesaikan materi } \\
\text { pelajaran }\end{array}$ & & $70 \%$ & \\
\hline 5 & $\begin{array}{l}\text { Melaksanakan materi } \\
\text { dengan benar }\end{array}$ & $70 \%$ & $70 \%$ & \\
\hline 6 & $\begin{array}{l}\text { Melaksanakan semua } \\
\text { materi }\end{array}$ & & $70 \%$ & \\
\hline
\end{tabular}

Berdasarkan tabel 2, menunjukkan bahwa penguasaan materi pelajaran pendidikan agama memiliki 6 indikator penilaian terhadap bahan ajar shalat sunnat.

Penguasaan materi pelajaran tentang pelaksanaan shalat sunnat pada anak berkebutuhan khusus (tunanetra) belum menggambarkan adanya perubahan yang signifikan dalam mendefinisikan materi pelajaran. Walaupun perubahan dalam menyelesaikan dan melaksanakan materi secara berurut dan benar belum efesien, tetapi tidak mengurangi nilai pada pengetahuan dan kemampuan yang dimiliki siswa tunanetra (Ibrahim Yusuf).

Contoh: Ibrahim Yusuf, Rangky Sulaiman, dan Kifly (siswa kelas A), sudah bisa melafalkan surat-surat pendek, adzan, memimpin shalat (imam) dan berudhu dengan benar. (observasi).

Penerapan pembelajaran tata cara shalat sunnat pada anak berkebutuhan khusus dilaksanakan secara individu dengan pembiasaan. Pada prinsipnya, bagaimana siswa bisa mengenal dan dapat mengaplikasikan. Pembinaan dan bimbingan shalat tidak hanya secara teori tetapi diperkuat lewat praktik, karena anak berkebutuhan khusus (tunanetra) lebih cendrung pada gerakan.

Pelaksanaan pembinaan dan bimbingan tidak hanya diruang kelas, tetapi diaplikasikan setiap lima waktu di mushallah ataupun di asrama (putra/ putri). Sedangkan yang bertanggungjawab dalam membimbing dan membina anak berkebutuhan khusus (tunanetra) selain guru agama, guru kelas, dan guru khusus, serta pengasuh asrama. (wawancara guru agama Ibu Nangsi Pakaya, $19 / 3 / 2013)$.

\section{Kegiatan Penutup}

Kegiatan penutup dalam pembelajaran tematik tidak hanya diartikan sebagai kegiatan untuk menutup pelajaran, tetapi juga sebagai kegiatan penilaian hasil belajar pserta didik. Waktu yang tersedia dalam kegiatan penutup relatif singkat, oleh karena itu guru perlu mengatur dan memanfaatkan waktu seefisien mungkin. Sifat dari kegiatan penutup adalah menenangkan. Beberapa contoh kegiatan penutup yang bisa dilakukan dalam pembelajaran tematik diantaranya dengan menyimpulkan hasil pembelajaran yang dilakukan, bercerita, menyampaikan pesan moral, memberikan tugas atau latihan (Trianto, 2011:219).

Penggunaan alokasi waktu kegiatan penutup 10 menit, pembelajaran ini merupakan kegiatan refleksi dengan mengakumulasikan hasil pembelajaran inti, agar siswa lebih mudah mengenal materi yang telah diajarkan. Kemudian guru bisa mengukur tingkat pengetahuan dan kemampuan siswa, terhadap pemahaman dalam penguasaan materi pelajaran pendidikan agama (shalat sunnat).

\section{Penilaian dan Evaluasi Pembelajaran}

Pengukuran merupakan

suatu

proses pemberian skor atau angka-angka terhadap suatu keadaan atau gejala berdasarkan atura-aturan tertentu. Dengan demikian terdapat kaitan yang erat antara pengukuran (measurment) dan evaluasi. Kegiatan pengukuran merupakan dasar dalam kegiatan evaluasi.

Evaluasi adalah proses mengumpulkan dan menyajikan suatu informasi yang bermanfaat untuk pertimbangan dalam pengambilan keputusan. Tujuan evaluasi pembelajaran adalah untuk menghimpun informasi yang dijadikan dasar untuk mengetahui taraf kemajuan, perkembangan, dan pencapaian belajar siswa, serta keefektifan pengajaran guru. Evaluasi pembelajaran mencakup kegiatan pengukuran dan penilaian. Bila ditinjau dari tujuannya, evaluasi pembelajaran dibedakan atas evaluasi diagnostik, selektif, penempatan, formatif dan sumatif. Bila ditinjau dari sasarannya, evaluasi pembelajaran dapat 
dibedakan atas evaluasi konteks, input, proses, hasil dan out come. Proses evaluasi dilakukan melalui tiga tahap yaitu tahap perencanaan, pelaksanaan, pengolahan hasil dan pelaporan.

Evaluasi sumatif adalah evaluasi yang dilaksanakan setelah sekumpulan program pelajaran selesai diberikan. Dengan kata lain evaluasi yang dilaksanakan setelah seluruh unit pelajaran selesai diajarkan. Adapun tujuan utama dari evaluasi sumatif ini adalah untuk menentukan nilai yang melambangkan keberhasilan peserta didik setelah mereka menempuh program pengajaran dalam jangka waktu tertentu (Sudijono, 2007: 23).

Implementasi penilaian dan evaluasi pembelajaran pada anak yang berkebutuhan khusus (tunanetra) dilakukan secara akademik dan perubahan perilaku. Adapun sumber penilaian, sebagai berikut: akademik, guru agama memberikan penilaian lewat kompetensi siswa, melalui tes tulisan, lisan, dan praktik. Contoh: Fiqih (tata cara shalat); soal-soal yang diberikan kepada siswa adalah seputar tentang shalat, bacaan dan niat shalat, serta memperaktekkan cara berwudhu dan melaksanakan shalat. Perubahan perilaku, guru agama memberikan penilaian lewat pengamatan, dimana ada beberapa kriteria yang dijadikan sebagai dasar penilaian diantaranya: disiplin (melaksanakan tepat waktu) dan tertib (melaksanakan shalat), serta terbiasa melaksanakan ibadah (shalat) tanpa menunggu instruksi atau komando dari guru. (wawancara pembimbing rohani Karim Idrus, 20/3/2013).

Penyusunan penilaian dan evaluasi hasil pembelajaran, dilakukan secara terstruktur. Tenaga pendidik (guru agama dan guru khusus) mengakumulasi berbagai kreteria penilaian berdasarkan kompetensi peserta didik (tunanetra). Sedangkan penyusunan alat evaluasi yang digunakan dalam penilaian, diantaranya: Penilaian daftar tatap muka, analisis hasil ulangan harian (tertulis, lisan pengamatan/perbuatan, tugas pekerjaan rumah, portofolio dan tindak lanjut ulangan harian dengan melihat klasifikasi nilai perolehan dan jenis.

Contoh: pengklasifikasian penilaian, yaitu: Nilai rata-rata ulangan harian (skor perolehan, jumlah skor, nilai, serta criteria ketuntasan penilaian) dan pengamatan/ perbuatan kemudian ditambahkan dengan nilai rata-rata tugas pekerjaan rumah serta nilai semester. (bimbingan khusus guru mata pelajaran, mengerjakan soal-soal dari kompetensi dasar yang belum tuntas, membuat ikhtisar dari pokok bahasan yang diajarkan, membuat tugas proyek, membimbing temantemannya yang mengikuti perbaikan dengan perolehan nilai 4,50-54,9, menyelesaikan soalsoal dari berbagai buku sumber kepustakaan yang relevan dengan materi yang dijarkan, dan memperdalam materi pelajaran sesuai dengan materi yang diajarkan. Nilai 85-100 tugas $E$, 75-84 tugas $F, 65-74,9$ tugas $G$, 5564,9 tugas $B, 45-54,9$ tugas $B, C / B, D$ dan 44,9 tugas $A, B, C)$.

\section{Model Pembelajaran}

Seseorang dikatakan mempunyai intelegensi yang tinggi jika ia dapat menjawab dengan cepat suatu masalah, baik dengan jawaban maupun dengan perbuatan. Perbuatan intelegesi sifatnya serasi tujuan dan ekonomis untuk mencapainya. Masalah yang dihadapi merupakan masalah yang baru bagi dirinya (Bendi, 2003: 6).

Ada beberapa pengertian yang dikemukakan oleh para ahli diantara pengertian-pengertian kebiasaan adalah:1) Kebiasaan adalah tingkah laku yang cenderung selalu ditonjolkan oleh individu dalam menghadapi keadaan tertentu, 2) Kebiasaan merupakan proses "Internalisasi" dari norma masyarakat, dan adanya kematangan dari sudut organik biologik yang diwujudkan dalam perilaku sadar, 3) Kebiasaan merupakan hasil dari rangkaian rangsang dan jawaban yang dipelajari oleh anak dan dilakukan secara berkesinambungan. Jadi latihan pembiasaan merupakan upaya yang intensif untuk menciptakan lingkungan sebagai sumber dari timbulnya tingkah laku, yang cenderung selalu ditonjolkan oleh individu sebagai proses internalisasi dari norma-norma lingkungan agar diperoleh kematangan dan perkembangan kepribadian yang optimal (Prayitno, 2010: 63).

Pengembangan pembelajaran yang diimplementasikan pada lembaga Sentra PK/PLK SLB Kabupaten Gorontalo lewat pendidikan agama, bertujuan untuk membentuk suatu perubahan perilaku terhadap anak yang berkebutuhan khusus dengan cara pengembangan diri baik secara 
akademik maupun keterampilan. (wawancara Nangsi Pakaya, 19/3/2013).

Pelaksanaan pembelajaran pendidikan agama dalam hal belajar mengajar tidak hanya guru agama yang memberikan materi dan bimbingan, tetapi para wali kelas dan guru khusus ikut bertanggung jawab dalam membentuk perubahan pola pikir dan perilaku peserta didik. Karena anak yang berkebutuhan khusus dalam menyerap, mengenal, dan memahami materi pendidikan agama, dilakukan secara pembiasaan, makanya para tenaga pendidik dituntut untuk kreatif dan inovasi dalam memberikan materi terhadap siswa. (wawancara Ibu Hartati R. Buhungo guru khusus A, 21/3/2013).

Perubahan sikap dan perilaku siswa setelah memahami tata cara shalat, setiap masuk waktu shalat anak (tunanetra) bergegas untuk berwudhu, dan adzan, serta memimpin shalat secara berjamaah. Sedangkan kemampuan dan pengetahuan siswa tunanetra, terhadap pemahaman kitab Alquran, masih dalam tahap menghafal huruf dan surat-surat pendek, bacaan shalat, dan doa-doa.

Efektifitas pembelajaran pendidikan agama pada anak berkebutuhan khusus (tunanetra) terlaksana, karena guru menggunakan metode ceramah dan demonstrasi serta media pembelajaran berdasarkan materi/bahan ajar kemudian disesuaikan dengan kebutuhan dan kemampuan peserta didik. (wawancara Abd. Karim Idrus pembina rohani, 20/3/2013).

\section{Faktor-Faktor Pendukung Dan Penghambat Pembelajaran Pendidikan Agama}

Keberhasilan proses pembelajaran ditentukan oleh banyak faktor, diantaranya adalah guru. Guru merupakan komponen yang sangat menentukan dalam implementasi model pembelajaran. Keberhasilan penerapan model pembelajaran ini terutama berhubungan dengan kualitas atau kemampuan yang dimiliki oleh guru. Berikut ini beberapa aspek yang mempengaruhi kemampuan guru dalam mengimplementasikan. Siswa, siswa adalah organisme yang unik yang berkembang sesuai dengan tahap perkembangannya.

Perkembangan anak adalah perkembangan seluruh aspek kepribadiannya, akan tetapi tempo dan irama perkembangan masing-masing anak pada setiap aspek tidak selalu sama. Sarana dan
Prasarana, sebagai suatu pusat pendidikan, karena tiap sekolah telah memiliki ruang kelas, ruang kepala sekolah, ruang guru, kamar kecil (WC) dan halaman tempat dilakukannya aktivitas di luar kelas. Selain itu juga sekolah telah dilengkapi dengan prasarana yang memadai, seperti penerangan dan jalan menuju sekolah yang cukup baik, serta lingkungan.

Peningkatan kualitas pembelajaran pendidikan agama di Sentra PK/PLK SLB Kabupaten Gorontalo pada anak yang berkebutuhan khusus (tunanetra), harus ditunjang dari berbagai aspek komponen pendidikan, baik secara internal maupun eksternal.

\section{Pendukung Pembelajaran}

Tenaga pendidik memodifikasi kurikulum berdasarkan kebutuhan dan kemampuan siswa serta lebih besar alokasi waktu praktik dibanding teori, karena anak berkebutuhan khusus cendrung pada gerakan (praktik) dalam menyerap, mengenal dan memahami materi pendidikan agama (shalat), serta diperkuat lewat bimbingan rohani.

Metode dan strategi serta media/alat pembelajaran yang digunakan disesuaikan berdasarkan bahan ajar, misalnya: berdoa, berniat, berwudhu, dan bacaan shalat serta yang terkait dalam pelakasanaan shalat.

Strategi pembelajaran yang diterapkan dalam merubah perilaku siswa dengan cara pembiasaan dan kreatifitas, serta kesabaran dan kepedulian guru yang tinggi dalam memberikan bimbingan dan pembinaan baik di ruang kelas maupun di luar, dintaranya: beribadah (shalat dan puasa) dan interaksi sosial (berprilaku) serta bagaimana menggunakan bahasa yang baik dalam berkomunikasi (menghargai dan menghormati) orang tua, guru, dan sesama teman baik dilingkungan sekolah maupun di luar sekolah.

\section{Penghambat Pembelajaran}

Kondisi di Sentra PK/PLK SLB Kabupaten Gorontalo dalam pelaksanaan pembelajaran pendidikan agama secara keseluruhan, fasilitas pembelajaran belum menunjang (media/alat) peraga pembelajaran, dan reverensi (buku-buku) yang relevan dengan pendidikan agama serta buku iqra yang sangat terbatas. Sebahagian besar orang tua siswa membebankan sepenuhnya kepada 
pihak lembaga dalam membina dan mendidik anaknya, sehingga para guru memiliki beban dan tanggungjawab yang besar dalam merubah/ membentuk pola pikir dan perilaku siswa.

Pembelajaran dilakukan secara integrasi dan guru agama memiliki keterbatasan pengetahuan ke-PLB-an, sehingga dalam mentransformasikan materi pendidikan agama kurang efektif. Lembaga Sentra PK/PLK SLB Kab. Gorontalo, lebih berkonsentrasi pada pelakasanaan pembelajaran umum (akademik dan keterampilan) dibanding pelaksanaan pembelajaran pendidikan agama.

\section{PENUTUP}

Berdasarkan hasil analisis tentang proses pelaksanaan pembelajaran pendidikan agama pada anak yang berkebutuhan khusus (tuna netra), di Sentra PK/PLK SLB Kabupaten Gorontalo. Bahwa pedoman pembelajaran pendidikan agama pada Sentra PK/PLK SLB Kabupaten Gorontalo bersumber pada kurikulum Dirjen Manajemen Pendidikan Dasar Menengah dan Direktorat Pembinaan Sekolah Luar Biasa (SLB) tahun 2006.

Metode ceramah yang digunakan dalam proses pembelajaran, strategi pembelajaran terencana, terlaksana, dan terevaluasi, serta media/alat pembelajaran elektronik dan manual, sedangkan pelaksanaan pembelajaran dikondisikan pada bahan/materi ajar Fiqih (memahami tata cara shalat sunnat). Pelaksanaan pembelajaran dilakukan secara integrasi pada jenjang dan tingkat berdasarkan disabilitas (dikondisikan). Karena, secara kuantitas siswa dan guru agama relatif kurang sehingga pemahaman siswa terhadap pendidikan agama dominan lewat pembinaan dan bimbingan rohani yang dilaksanakan setiap hari di mushallah.

Faktor pendukung dan penghambat dalam pelaksanaan pembelajaran pendidikan agama pada ABK (tunanetra) di Sentra PK/PLK SLB Kabupaten Gorontalo, sebagai berikut: faktor pendukung; kurikulum disesuaikan dengan kemampuan dan kebutuhan siswa, sistem pembelajaran berdasarkan hasil kesepakatan antara lembaga dan komite, alokasi waktu praktik lebih besar dibanding teori, dan perubahan perilaku siswa dominan lewat bimbingan rohani, dan pelaksanaan pembelajaran dilakukan dengan pembiasaan, serta kepedulian dan kesabaran guru yang tinggi dalam mengajar dan mendidik. Pembinaan diperkuat lewat bimbingan rohani, kegiatan ekstrakurikuler, dan kegiatan latihan dasar kepemimpinan (LDK) saat bulan Ramadhan. Sedangkan faktor penghambat; kurangnya pengetahuan dan wawasan orang tua siswa dalam membina anaknya, tenaga pendidik memiliki keterbatasan pengetahuan ke-PLB-an sehingga inovasi dan kreatifitas dalam memberikan materi belum efektif, dan fasilitas (media dan alat) peraga pembelajaran pendidikan agama kurang menunjang (misalnya perlengkapan shalat), serta reverensi (buku agama dan iqra) yang sangat terbatas.

\section{UCAPAN TERIMA KASIH}

Penelitian ini dibiayai oleh DIPA Litbang Agama Makassar Tahun 2013. Ucapan terima kasih diperuntukkan kepada para informan dilapangan khususnya para responden, juga terima kasih kepada teman-teman peneliti terkhusus bidang pendidikan agama dan keagamaan pada Balai Penelitian Dan Pengembangan Agama Makassar atas masukan dan kebersamaan kita selama ini.

\section{DAFTAR PUSTAKA}

Abdurrahman, Mulyono. 2003. Pendidikan Bagi Anak Berkesulitan Belajar. Depdikbud Dirjen Pendidikan Tinggi Proyek Pendidikan Tenaga Akademik. Jakarta: Rhineka Cipta.

Bendi Delphie. 2003. Psikologi Perkembangan Anak Yang Berkebutuhan Khusus. Jakarta: Rineka Cipta.

Harun, Salman. 1984. Sistem Pendidikan Islam. Bandung: Al-Maarif

Kementerian Agama Kabupaten. 2013. Data Guru Agama dan Pengawas PAI. Kabupaten Gorontalo.

Keputusan Bersama Menteri Kemeniknas Dan Kemenag Nomor 570 tahun 1999, Pelaksanaan Pendidikan Agama Pada Satuan Pendidikan Dasar Dan Menengah.

Nuraeni. 1997. Intervensi Dini Bagi Anak Bermasalah. Jakarta: Rineka Cipta.

Prayitno. 1997. Bimbingan Pribadi. Jakarta: Rineka Cipta

Profil SLB Sentra PK/PLK Kabupaten Gorontalo

Sagala, Saiful. 2005. Manajemen Berbasis Sekolah 
Dan Masyarakat. Jakarta: Nimas Multima. Sudijono. 2007. Pengantar Evaluasi Pendidikan. Jakarta: Raja Grafindo Persada.

Thoha, Chabib (eds). 1999. Metodelogi Pengajaran Agama. Yogyakarta: Pustaka Pelajar.
Trianto. 2007. Pelaksanaan Model Pembelajaran Tematik Kelas Dasar. Bandung: Rosdakarya. Undang-Undang Nomor 20 Tahun 2003 tentang Sistem Pendidikan Nasional. 